\title{
Modes of Inheritance of Photoperiodism in Fragaria
}

\author{
Hamid Ahmadi, Royce S. Bringhurst, and Victor Voth \\ Department of Pomology, University of California, Davis, CA 95616
}

Additional index words. day-neutral, everbearing strawberries, photo-insensitivity

\begin{abstract}
Genetic analysis of day-neutral (photo-insensitive) cultivars and their derivatives hybridized to standard short-day clones of octoploid strawberries [Fragaria $\times$ ananassa Duchn., F. chiloensis (L.) Duchn., and $F$. virginiana glauca Staudt., $\mathrm{x}=7,2 \mathrm{n}=56$ ] revealed that photo-insensitivity is controlled by a single dominant allele of a Mendelian gene. The dominant genetic trait is expressed in hybrids with other Fragaria spp. Intergeneric hybrids of day-neutral Fragaria and short-day Potentilla glandulosa L. and $P$. fruticosa L. also express photo-insensitivity. The day-neutral genes in European perpetual flowering (photo-insensitive) diploid 'Alpine' F. vesca $(2 \mathrm{~N}=14)$ apparently have evolved independently, since photo-insensitivity is recessive to photo-sensitivity. Native California diploid $F$. vesca have diverged considerably from European $F$. vesca. No photo-insensitive diploids have been found among them. Photo-sensitivity in native California $F$. vesca is controlled by three dominant genes. The origins of day-neutral cultivars of $F . \times$ ananass $a$ and the classification of day-neutrality are discussed.
\end{abstract}

Photoperiodism in flowering plants was first described in 1918 in short-day tobacco mutants (Garner and Allard, 1920). Subsequently, the angiosperms were classified as short-day (SD), long-day (LD), and photo-insensitive or day-neutral (DN), according to the daylight regime that induces flower bud initiation. The body of literature on photo-sensitivity in flowering plants indicates that the phenomenon is frequently controlled by a single gene or by very few genes or gene complexes (Chailakhyan, 1979; Skripchinsky, 1971; Bernier et al., 1981). Induction or repression of single genes or their products appears to act upon the meristematic tissue at the earliest stage of organogenesis and disrupt the regulation otherwise imposed by the interaction of genetic factors with environmental stimuli. This pattern apparently confers photo-insensitivity (Skripchinsky, 1971).

In rice (Chandrartna, 1953, 1955), tetraploid sea island cotton (Gossypium barbadense; Lewis and Richmond, 1960), subterranean clover (Salisbury et al., 1987), Canadian wheat (Knott, 1986), sweet, pea (Ross and Murfet, 1985), and jute (Joshae and Thakare, 1986), photo-sensitivity is controlled by a dominant allele of a single gene. In contrast, day-length sensitivity is conferred by a recessive gene in okra (Wyatt, 1985), cucumber (Della and Peterson, 1984), and upland tetraploid cotton ( $G$. hirsutum; Lewis and Richmond, 1957). Thus, in cotton, Lewis and Richmond (1957) concluded that day-neutrality evolved independently in the two species. The recessive allele of G. barbadense is not expressed in the genetic background of upland cotton (G. hirsutum). In a few cases, the inheritance of photoperiodism is more complicated. In pea (Ross and Murfet, 1986) and in some hexaploid wheat (Maystrenko and Aliev, 1986), two dominant alleles of two genes are involved. In sesame, three genes (Kotecha et al., 1975) are responsible for short-day sensitivity.

Some investigators have implied that florigen and antiflorigen metaphoric substances have roles in perpetual flowering (Lang, 1984), while others believe that the elimination or exclusion of inhibitors causes day-neutrality (Ross and Morfet, 1986; Guttridge, 1959). In most investigations, pleiotropic effects, such as dwarfing and low yields, are observed. Other correlated effects caused by modifier genes, such as earliness, vernalization,

Received for publication 14 Feb. 1989. The cost of publishing this paper was defrayed in part by the payment of page charges. Under postal regulations, this paper therefore must be hereby marked advertisement solely to indicate this fact. etc., have also been reported. Finally, some authors reported the induction of day-neutrality in sensitive plants by mutagens, such as X rays, while others have recovered spontaneous dayneutral mutants in populations of short- or long-day plants (Skripchinsky, 1971).

Our study is devoted toward the elucidation of the inheritance of photoperiodism in Fragaria spp. Genetic evidence is presented to support the postulation that a dominant allele of a single Mendelian gene induces day-neutrality in the octoploids and that recessive alleles of one to three genes confer it in the diploids.

Origins of the day-neutral Fragaria. European investigators discovered diploid "perpetual-flowering" ('Alpine') types as early as the 17th Century. Other perpetual-flowering clones have since been reported in Europe, e.g., 'F. de Gaillon', selected by Labaute in France in 1811 (Richardson, 1913-14) and 'Baron Solemacher', selected in Germany. Brown and Wareing (1965) concluded that a single recessive gene induced day-neutrality in short-day diploid European $F$. vesca.

Studies suggest three independent sources of photo-insensitive octoploid cultivars $(F . \times$ ananassa $)$. First, European "everbearing" (day-neutral $=$ photo-insensitive $)$ cultivars are derivatives of 'Gloede' seedlings introduced in France in 1866 (Richardson, 1913-14). Abbe Thivolet selected 'St. Joseph' in 1893 and later 'St. Antoine de Padoue'. L. Gauthier hybridized 'St. Antoine de Padoue' with 'Louis Gauthier', a white-fruited berry, and selected 'Merveille de France', introducing it in 1904 (Darrow, 1966). Richardson (1913-14), in his pioneering study of perpetual flowering, used 'St. Antoine de Padoue' and its seedlings and 'Laxton's Perpetual' hybridized to short-day 'Bedford Champion' (Richardson, 1913-14).

The second original source of the day-neutral octoploid strawberry was probably a chance seedling or a clonal mutation of 'Bismark' found in New York by S. Cooper. He selected dayneutral 'Pan American' in 1898 (Darrow, 1966). Later, H. Rockhill, in 1904, crossed this cultivar with 'Dunlap' to obtain 'Progressive', from which he bred 'Rockhill' (Fig. 1, top left).

The third major synthesis of day-neutral plants was reported by Bringhurst and Voth (1980). They collected late-fruited $F$. virginiana glauca plants from the Wasatch mountains near Salt Lake City, Utah, in 1954 and selected day-neutral plants among the offspring of the first backcross hybrids to short-day parents and introduced three new day-neutral cultivars in 1979; 'Aptos', 'Hecker', and 'Brighton' (Fig. 1, lower left); 'Fern' (Fig. 1, 

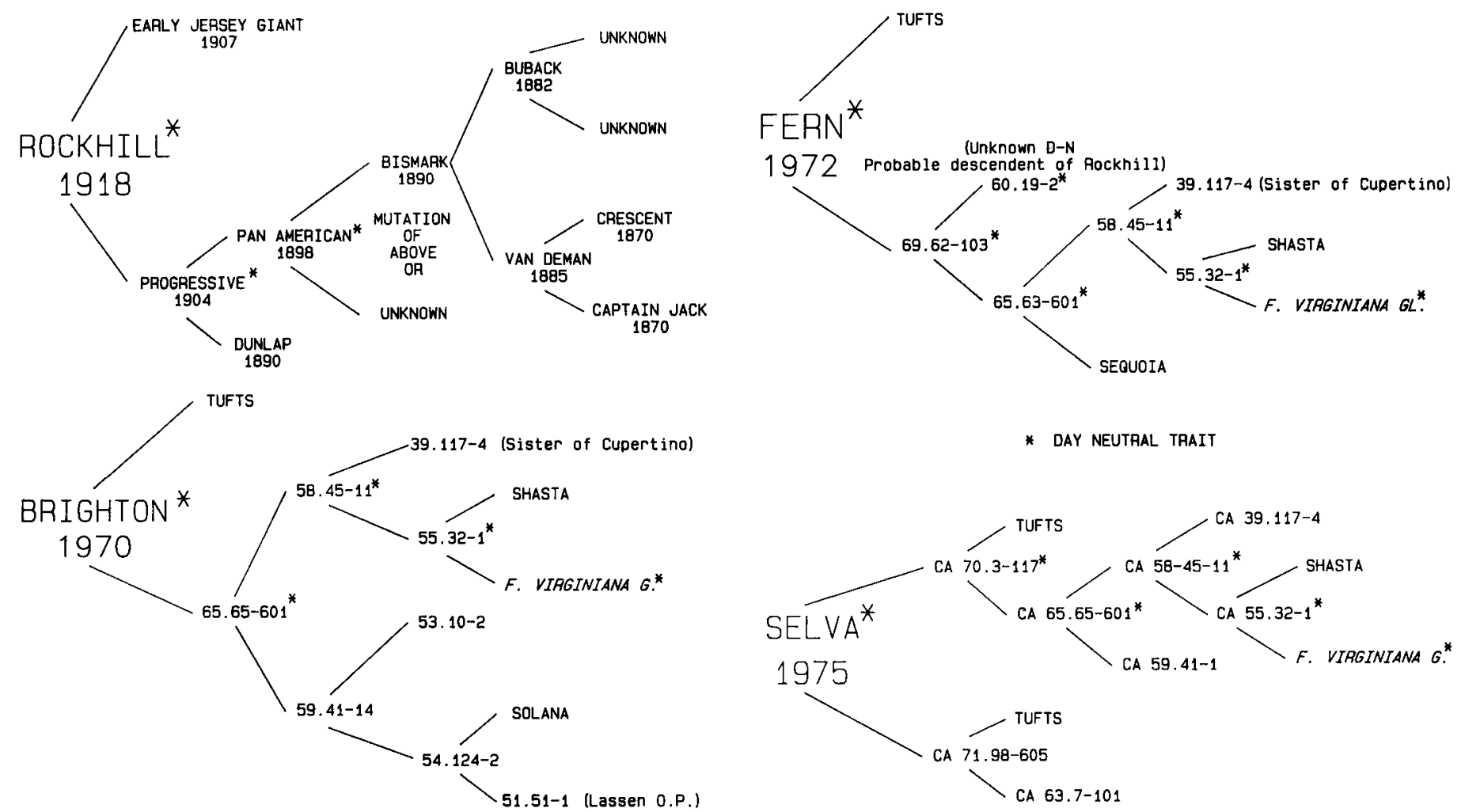

Fig. 1. Pedigree of 'Rockhill' (top left), originated in 1918, released in 1923; pedigree of 'Brighton' (lower left), originated in 1970, released in 1979; Pedigree of 'Fern' (top right), originated in 1972, released in 1983; Pedigree of 'Selva' (lower right), originated in 1975, released in 1983.

top right) in 1983; 'Selva' in 1983 (Fig. 1, lower right); and 'Muir', 'Mrak', and 'Yolo' in 1988. Powers (1954) and Darrow (1937) had mentioned previously the possibility of F. Virginiana glauca as a potential source of the everbearing character.

\section{Materials and Methods}

Day-neutrality in diploid F. vesca $(x=7,2 N=14)$. A dayneutral European vesca with the diagnostic electrophoretic genetic marker phosphoglucoseisomerase (EC 5.3.1.9) was hybridized with male-sterile short-day clones of $F$. vesca from Hecker Pass, Calif. The seeds were germinated in the greenhouse and plants were established in the field in 1986. Selected hybrids were selfed $\left(\mathrm{F}_{2}\right)$ and crossed to 'Alpine vesca' (BC1). The offspring were planted and scored in the greenhouse 1 to 3 months after planting. Day-neutral plants flowered 6 to 8 weeks after germination. The same clone of 'Alpine vesca' was hybridized with a female $F$. chiloensis $(8 \mathrm{X})$ clone (CA Accession $1234=$ CMC 1234), yielding vigorous semi-sterile pentaploid offspring. The chromosomes of hermaphroditic pentaploids of this cross were doubled with colchicine; a fully fertile decaploid was selfed, and the decaploid offspring were scored for photoperiodic reaction in Oct. 1988.

Classification of day-neutral octoploid Fragaria. Many authors have classified day-neutrality on the basis of fruiting pattern, particularly for the late harvest data (Bringhurst et al., 1989). Some have used variation in growth habits and flowering (Nicoll and Galletta, 1987). In this report, four identification criteria were used:

1) Flowering of mother and runner plants in the nursery during the summer and fall.
2) Germination of seeds and establishment of seedlings in the fields in early spring and scoring them for flowering 3 to 5 months later, in mid- to late summer or early fall.

3) Continuous cycles of flowering during the second year on plants established in the field in the fall of the first year and subjected to the extreme heat of the summer in the Sacramento Valley, Calif.

4) Classification of the parents based on the flowering pattern of their seedlings, i.e., hybridizing the standard short-day $F$. chiloensis with the suspected heterozygous DN cultivars and rearing their offspring as described in category 2.

Day-neutrality in breeding populations (1977, 1983, 1985, 1986, and 1987). Standard short-day (SD) and day-neutral (DN) cultivars and their derivatives were hybridized in the greenhouse in the late winter and spring of 1983 and 1985 through 1987. Seeds were germinated in July. Seedlings were transplanted once in the greenhouse and established in the field in late September in the Sacramento Valley (Winters, Calif.). Individual plants were scored as DN after the flowers and fruits appeared in July, August, or September of the 2nd year. The total population varied from 8000 to 14,000 plants each year. The 1977 seeds were germinated in Feb. 1978, planted in the field in Apr. 1978, and scored in June, July, August, and September of the same year.

Diallel experiment, 1987. Four SD plus four DN clones were intercrossed in all combinations and 64 families were established in the field as explained above in two randomized blocks with six plants in each block and in two locations at Winters (Sacramento Valley) and at Watsonville, Calif. (Central Coast). The seedlings were scored for day-neutrality as described in the 
previous section. Three parents were early fruiting, two were intermediate, and the rest were late-fruiting. In addition, one of the parents was considered a weak DN and one was classified as strong. A weak DN clone produces few flowers and only on the mother and first daughter runner plants, whereas the strong DN cultivar flowers profusely on all runner plants in the nurseries in California in the summer and fall. However, the offspring of a weak DN parent may segregate for strong and weak day-neutrality in the same manner as the offspring of a strong DN parent (data not presented).

Hybridization between octoploids F. $\times$ ananassa and F. chiloensis and F. virginiana. Day-neutral 'Hecker' and 'Brighton' were hybridized with two male $F$. chiloensis clones, one from northern coastal California (Point St. George = PSG15) and the other from central coastal California (Ano Nuevo = AN2). The seeds were germinated in July. Seedlings were planted in the field in Sept. 1983 and scored in late Summer 1984. Selected DN hybrids were selfed and backcrossed to standard SD clones and scored in the subsequent year. Additional crosses were made later between day-neutral 'Fern' and CN25 and short-day $F$. chiloensis clones CA 1466 (from Point St. George, north coastal California), CA 1234 (from Cape Mendocino, north coastal California) and 'OSF-4' (from Oso Flaco Lake near Santa Maria, south central coastal California). Their seedlings were classified for day-neutrality. Their sexual reproduction cycles were compared with the flowering habit of the hybrids of SD F. $\times$ ananassa and $F$. chiloensis as standards. 'Selva', 'CN25', 'Fern', and 'Mrak', were also intercrossed with a high-elevation, latefruiting $F$. virginiana glauca clone from Luther Pass, Calif., in 1987 and their seedlings were scored in Winters, Calif., in 1988.

Breeding homozygous day-neutrals. 'Fern' and 'Mrak' (DN cultivars) were selfed twice. Twelve S2 seedlings were randomly selected and selfed again. Sixty S3 seedlings of the S2 generation were scored and tested for day-neutrality in the greenhouse. A relatively vigorous DN self of 'Mrak' ('Mrak S1') and two seedlings of 'Fern S2' (Fern S2\#5 and \#6) were selected, tested again for homozygosity of day-neutrality, and then used for genetic analysis of the DN habit. The presumed "homozygous" DN clones were then intercrossed with standard (SD) cultivars 'Douglas' and 'Pajaro', with (SD) F. chiloensis and with (SD) high-elevation $F$. virginiana glauca (Luther Pass, $F$. virginiana GL 546) clones. The $\mathrm{F}_{1}$ seeds were germinated in February and the seedlings were transplanted in the field in April and examined frequently from August to the end of November. Selected hybrids were selfed $\left(\mathrm{F}_{2}\right)$ and backcrossed to the SD cultivars Pajaro and Sequoia $(\mathrm{BCl})$; their offsprings were scored in the same fashion.

Intergeneric hybridization of day-neutral Fragaria with Potentilla species. Day-neutral 'Fern' was hybridized to P. fruti$\cos a(\mathrm{X}=7,2 \mathrm{~N}=28)$ and seeds were germinated aseptically in solid minimal nutrients with $0.5 \mathrm{mg} \mathrm{GA} /$ liter and transplanted in the greenhouse after 6 weeks. 'Hecker', 'Brighton', and 'Fern', standard DN cultivars, were hybridized to $F$. chiloensis SD clones first. Their DN hybrids were then intercrossed with $P$. glandulosa ssp. Nevadensis $(x=7,2 \mathrm{~N}=14)$. The seeds were germinated and reared in the greenhouse. Later, they were tested electrophoretically to authenticate intergeneric hybridity and scored for day-neutrality.

\section{Results}

Day-neutrality in diploid Fragaria vesca. Day-neutrality in the alpine strain of $F$. vesca is controlled by recessive genes, in contrast to dominance in $F$. $\times$ ananassa. Hybridization of
SD with DN strains of the European vesca supported the postulation of single gene control of the trait within the subspecies; however, the preliminary result of the crossing of European 'Alpine' strain to native vesca of California was different and showed involvement of more than two genes. Therefore, a simple Mendelian genetic analysis was devised to test the hypothesis of a three-gene model of day-neutrality. The data in Table 1 clearly show that $\mathrm{F}_{1}$ seedlings were all SD, as expected; however, individuals in the $\mathrm{F}_{2}$ and $\mathrm{BCl}$ populations segregated 1:63 and $1: 7$, respectively, for day-neutrality.

Hybridization of 'Alpine' ( $F$. vesca) to SD clones of $F$. chiloensis yielded SD pentaploid offspring only, and their derived decaploid was SD. However, three seedlings among 148 offspring of the selfed decaploid flowered in Fall 1988, $\approx 5$ months after the seed germination.

Evaluation of photoperiodism in the octoploid breeding populations. Advanced DN cultivars and their promising DN derivatives were intercrossed or hybridized to SD cultivars. Seedlings were tested in mid- to late summer and scored for day-neutrality after sexual reproduction in the SD segregants had ceased under the extreme summer heat. The results are presented in Tables 2 and 3. Short-day plants under the environmental stimuli in Davis, Calif., differed intrinsically from day-neutrals. Sexual reproductive cycles of DN segregants were extended, with repetitive fruiting peaks throughout the spring and summer, alternating with vegetative cycles in the summer. The runner plants also flowered. The SD segregants ceased to flower after a single main peak of fruit production in the spring, and produced runners only thereafter; the runner plants did not flower. Between $49 \%$ and $56 \%$ of the seedlings of day-neutrals hybridized to SD parents were day-neutrals. The DN parental clones and their advanced selections were exclusively heterozygous, with one homozygous exception. When day-neutrals were selfed or intercrossed $\approx 75 \%$ of the offspring were day-neutrals.

The results of the complete $8 \times 8$ diallel experiment of four DN and four SD parents are summarized in Table 4. The segregation ratios of the seedlings were $\approx 50 \%$ and $75 \%$ day-neutrals in hybrids of SD to DN parents and day-neutrals to dayneutrals, respectively. The photoperiodic results were conclusive, since they were not complicated by earliness or lateness of the parents even though the earliness character had considerable additive genetic variance (data not presented.) The classification of short-days vs. day-neutrals required the whole summer for completion, regardless of the strength of the day-neutrality trait of the parents.

Photoperiodism in interspecific and intergeneric hybrids. Heterozygous DN clones of $F . \times$ ananassa were hybridized to diploids $F$. vesca and F. viridis. About $50 \%$ of 20 pentaploid hybrids of 'Fern S2' by $F$. viridis and 'Mrak S1' by 'Alpine' vesca were DN and day-neutrality was persistent in their decacolchiploids. The results of the hybridization of DN clones of $F$. $\times$ ananassa with SD clones of $F$. chiloensis and late-fruited clone of $F$. virginiana glauca are summarized in Table 5.

Fragaria chiloensis seedlings are evergreen and usually flower in the 2 nd year of growth for a short time and only once. Thereafter, they behave the same as their transplanted runner plants. However, the DN hybrids of the two species $(F . \times$ ananassa and $F$. chiloensis) continuously produced flowers and fruit $\approx 4$ to 5 months after seed germination. The ratios of the DN to SD segregants were very close to the expected. However, $55 \%$ of the seedlings of 'Fern' $\mathrm{x} F$. virginiana glauca (clone 546) and $70 \%$ of hybrids of 'Mrak' by the same $F$. virginiana clone were still flowering and fruiting in late Sept. 1988. 
Table 1. Inheritance of the day-neutrality in $F$. vesca ${ }^{z}$

\begin{tabular}{|c|c|c|c|c|}
\hline \multirow[b]{2}{*}{ Parental types } & \multicolumn{2}{|c|}{ Distribution } & \multicolumn{2}{|c|}{ Ratio and fit } \\
\hline & DN & SD & $\mathrm{DN}: \mathrm{SD}$ & $P$ \\
\hline${ }^{y}$ Alpine vesca $x F$. vesca European $(\mathrm{F} 1)$ & 0 & 33 & $0: 1$ & 1.00 \\
\hline $\mathrm{y}\left(\mathrm{F}_{2}\right)$ observed & 16 & 65 & $1: 3$ & $>0.20$ \\
\hline $\mathrm{y}\left(\mathrm{F}_{2}\right)$ expected & $(20.25)$ & $(60.75)$ & & \\
\hline $\mathrm{y}\left(\mathrm{F}_{1}\right) \times$ Alpine vesca $\left(\mathrm{BC}_{1}\right)$ & 74 & 76 & $1: 1$ & $>0.90$ \\
\hline $\mathrm{y}\left(\mathrm{BC}_{1}\right)$ expected & $(75)$ & $(75)$ & & \\
\hline Cal $F$. vesca $\times$ Alpine vesca $(\mathrm{F} 1)$ & 0 & 127 & $0: 1$ & 1.00 \\
\hline $\begin{array}{l}\left(\mathrm{F}_{2}\right) \text { observed } \\
\left(\mathrm{F}_{2}\right) \text { expected }\end{array}$ & $\begin{array}{c}11 \\
(10.44)\end{array}$ & $\begin{array}{c}657 \\
(657.56)\end{array}$ & $1: 63$ & $>0.70$ \\
\hline $\begin{array}{l}\left(\mathrm{F}_{1}\right) \times \text { Alpine vesca }\left(\mathrm{BC}_{1}\right) \text { observed } \\
\left(\mathrm{BC}_{1}\right) \text { expected }\end{array}$ & $\begin{array}{c}18 \\
(17.56)\end{array}$ & $\begin{array}{c}122 \\
(122.5)\end{array}$ & $1: 7$ & $>0.90$ \\
\hline
\end{tabular}

${ }^{2} \mathrm{DN}=$ day-neutral; $\mathrm{SD}=$ short-day.

yBrown and Waring (1965).

Table 2. Genetic segregation of day-neutral (DN) vs. short-day (SD) seedlings in breeding populations.

\begin{tabular}{|c|c|c|c|c|c|c|c|}
\hline \multirow[b]{2}{*}{ Parental genotyes } & \multicolumn{4}{|c|}{ Observed (no.) } & \multicolumn{3}{|c|}{ Test and fit } \\
\hline & $\mathrm{DN}$ & SD & Total & Percent & Ratio & $x^{2}$ & $P$ \\
\hline $\begin{array}{l}\mathrm{SD} / \mathrm{SD} \times \mathrm{DN} / \mathrm{SD} \\
\mathrm{DN} / \mathrm{SD} \times \mathrm{SD} / \mathrm{SD} \\
\mathrm{DN} / \mathrm{SD} \times \mathrm{DN} / \mathrm{SD} \\
\mathrm{SD} / \mathrm{SD} \times \mathrm{SD} / \mathrm{SD} \\
\text { Total }\end{array}$ & $\begin{array}{r}1377 \\
1097 \\
1131 \\
0 \\
3605\end{array}$ & $\begin{array}{r}1345 \\
1110 \\
372 \\
400 \\
3227\end{array}$ & $\begin{array}{r}1978 \\
2722 \\
2207 \\
1503 \\
400 \\
6832\end{array}$ & $\begin{array}{l}50.6 \\
49.7 \\
75.2 \\
00.0\end{array}$ & $\begin{array}{l}1: 1 \\
1: 1 \\
3: 1 \\
0: 1\end{array}$ & $\begin{array}{l}0.38 \\
0.08 \\
0.05 \\
0.00\end{array}$ & $\begin{array}{l}0.5-0.7 \\
0.7-0.8 \\
0.8-0.9 \\
1.0\end{array}$ \\
\hline $\begin{array}{l}\mathrm{SD} / \mathrm{SD} \times \mathrm{DN} / \mathrm{SD} \\
\mathrm{DN} / \mathrm{SD} \times \mathrm{SD} / \mathrm{SD} \\
\mathrm{DN} / \mathrm{SD} \times \mathrm{DN} / \mathrm{SD}\end{array}$ & $\begin{array}{r}993 \\
1683 \\
2384\end{array}$ & $\begin{array}{r}934 \\
1594 \\
845\end{array}$ & $\begin{array}{l}1984 \\
1927 \\
3277 \\
3229\end{array}$ & $\begin{array}{l}51.5 \\
51.4 \\
73.8\end{array}$ & $\begin{array}{l}1: 1 \\
1: 1 \\
3: 1\end{array}$ & $\begin{array}{l}1.81 \\
2.42 \\
2.35\end{array}$ & $\begin{array}{l}0.1-0.2 \\
0.1-0.2 \\
0.1-0.2\end{array}$ \\
\hline $\begin{array}{l}\mathrm{DN} / \mathrm{DN} \times \mathrm{SD} / \mathrm{SD} \\
\quad \text { or } \mathrm{DN} / \mathrm{SD} \\
\mathrm{SD} / \mathrm{SD} \times \mathrm{SD} / \mathrm{SD} \\
\text { Total }\end{array}$ & $\begin{array}{r}555 \\
0 \\
5615\end{array}$ & $\begin{array}{r}0 \\
1000 \\
4373\end{array}$ & $\begin{array}{r}555 \\
1000 \\
9988\end{array}$ & $\begin{array}{l}100 \\
0.00\end{array}$ & $\begin{array}{l}1: 0 \\
0: 1\end{array}$ & $\begin{array}{l}0.00 \\
0.00\end{array}$ & $\begin{array}{l}1.0 \\
1.0\end{array}$ \\
\hline $\begin{array}{l}\mathrm{SD} / \mathrm{SD} \times \mathrm{DN} / \mathrm{SD} \\
\mathrm{DN} / \mathrm{SD} \times \mathrm{SD} / \mathrm{SD} \\
\mathrm{DN} / \mathrm{SD} \times \mathrm{DN} / \mathrm{SD} \\
\mathrm{SD} / \mathrm{SD} \times \mathrm{SD} / \mathrm{SD} \\
\text { Total }\end{array}$ & $\begin{array}{r}419 \\
501 \\
313 \\
0 \\
1233\end{array}$ & $\begin{array}{r}386 \\
435 \\
118 \\
1200 \\
2139\end{array}$ & $\begin{array}{r}1986 \\
805 \\
936 \\
431 \\
1200 \\
3372\end{array}$ & $\begin{array}{l}52.7 \\
53.5 \\
72.6 \\
0.00\end{array}$ & $\begin{array}{l}1: 1 \\
1: 1 \\
3: 1 \\
0: 1\end{array}$ & $\begin{array}{l}1.35 \\
4.65 \\
1.30 \\
0.00\end{array}$ & $\begin{array}{l}0.2-0.3 \\
0.05^{*} \\
0.2-0.3 \\
1.0\end{array}$ \\
\hline $\begin{array}{l}\mathrm{SD} / \mathrm{SD} \times \mathrm{DN} / \mathrm{SD} \\
\mathrm{DN} / \mathrm{SD} \times \mathrm{SD} / \mathrm{SD} \\
\mathrm{DN} / \mathrm{SD} \times \mathrm{DN} / \mathrm{SD} \\
\mathrm{SD} / \mathrm{SD} \times \mathrm{SD} / \mathrm{SD} \\
\text { Total }\end{array}$ & $\begin{array}{r}452 \\
634 \\
382 \\
0 \\
1468\end{array}$ & $\begin{array}{r}438 \\
600 \\
123 \\
1000 \\
2161\end{array}$ & $\begin{array}{r}1987 \\
890 \\
1234 \\
505 \\
1000 \\
3629\end{array}$ & $\begin{array}{l}50.8 \\
51.4 \\
75.6 \\
0.00\end{array}$ & $\begin{array}{l}1: 1 \\
1: 1 \\
3: 1 \\
0: 1\end{array}$ & $\begin{array}{l}0.22 \\
0.94 \\
0.11 \\
0.00\end{array}$ & $\begin{array}{l}0.5-0.7 \\
0.3-0.5 \\
0.7-0.8 \\
1.0\end{array}$ \\
\hline & & & 1988 & & & & \\
\hline $\mathrm{SD} / \mathrm{S}$ & 497 & 477 & 974 & 51.0 & $1: 1$ & 0.41 & $0.3-0.5$ \\
\hline $\mathrm{DN} / \mathrm{SD} \times \mathrm{SD} / \mathrm{SD}$ & 840 & 789 & 1629 & 51.6 & $1: 1$ & 1.60 & $0.2-0.3$ \\
\hline $\mathrm{DN} / \mathrm{SD} \times \mathrm{DN} / \mathrm{SD}$ & 799 & 283 & 1082 & 73.8 & $3: 1$ & 0.77 & $0.3-0.5$ \\
\hline $\mathrm{SD} / \mathrm{SD} \times \mathrm{SD} / \mathrm{SD}$ & 0 & 1000 & 1000 & 0.00 & $0: 1$ & 0.00 & 1.0 \\
\hline Total & 2136 & 2549 & 4685 & & & & \\
\hline
\end{tabular}

Five out of 12 intergeneric hybrids of 'Fern' and $P$. fruticosa were DN. 'Hecker', 'Brighton', and 'Fern' were hybridized to SD clones of $F$. chiloensis and their DN hybrids were intercrossed to $P$. glandulosa $(\mathrm{X}=7,2 \mathrm{~N}=14)$. Of these, about half of the 15 intergeneric hybrids were DN and produced flowers repetitively.

Homozygous day-neutral octoploids. Presumed "homozygous DN' plants 'Fern S2\#5', 'Fern S2\#6', and 'Mrak S1' 
Table 3. Comparison of the genetic segregation of day-neutral (DN) vs. SD of three studies with those of Powers (1954) and Richardson (1914).

\begin{tabular}{|c|c|c|c|c|c|}
\hline \multirow[b]{2}{*}{ Parental phenotypes } & \multicolumn{4}{|c|}{ Observed (no.) } & \multirow[b]{2}{*}{$\begin{array}{c}\text { Expected } \\
\text { ratio }\end{array}$} \\
\hline & $\mathrm{DN}$ & $\mathrm{SD}$ & Total & $\begin{array}{l}\text { Percent } \\
\text { DN }\end{array}$ & \\
\hline \multicolumn{6}{|c|}{ Breeding populations (Davis, Calif., 1978-88) } \\
\hline $\mathrm{SD} \times \mathrm{DN}$ & 3738 & 3580 & 7,318 & 51.08 & $1: 1$ \\
\hline $\mathrm{DN} \times \mathrm{SD}$ & 4755 & 4528 & 9,283 & 51.22 & $1: 1$ \\
\hline $\mathrm{DN} \times \mathrm{DN}$ & 5009 & 1741 & 6,750 & 74.21 & $3: 1$ \\
\hline $\mathrm{DN} / \mathrm{DN} \times \mathrm{DN}$ or $\mathrm{SD}$ & 555 & 0 & 555 & 100 & $1: 0$ \\
\hline $\mathrm{SD} \times \mathrm{SD}$ & 0 & 4600 & 4,600 & 0 & $0: 1$ \\
\hline Total & & & 28,506 & & \\
\hline \multicolumn{6}{|c|}{ Powers (1954) } \\
\hline $\mathrm{SD} \times \mathrm{DN}$ or $\mathrm{DN} \times \mathrm{SD}$ & 257 & 788 & 1,045 & 24.6 & $1: 3$ \\
\hline $\mathrm{DN} \times \mathrm{DN}$ & 85 & 66 & 151 & 56.3 & $9: 7$ \\
\hline Total & & & 1,196 & & \\
\hline \multicolumn{6}{|c|}{ Richardson (1913) } \\
\hline $\mathrm{SD} \times \mathrm{DN}$ & 24 & 53 & 77 & 31.2 & $1: 1$ \\
\hline $\mathrm{DN} \times \mathrm{DN}$ & 255 & 63 & 320 & 79.2 & $3: 1$ \\
\hline Total & & & 397 & & \\
\hline
\end{tabular}

were hybridized to SD clones of $F$. $\times$ anananssa, to $F$. chiloensis, and to $F$. virginiana. The $\mathrm{F}_{1}$ populations in all cases were exclusively DN. One-fourth of the population fruited early in summer, one-fourth flowered early in fall, and one-half of the seedlings were intermediate. The $\mathrm{F}_{2}$ and backcross populations were scored and the results are compatible with the assumption of a single dominant gene controlling day-neutrality (Table 6).

\section{Discussion}

Photoperiodism in diploid Fragaria species. All known diploid populations of Fragaria spp. $(\mathrm{X}=7,2 \mathrm{~N}=14)$ are shortday sensitive; however, mutant photo-insensitive strains have been identified among the wood strawberry ( $F$. vesca) populations of Europe. They were selected and brought under cultivation centuries ago. Day-neutral mutants of $F$. vesca have not been discovered in America. In fact, all perpetual flowering diploid F. vesca in America (e.g., Peru, Guatemala) and in Hawaii are feral 'Alpine' that have been introduced from Europe. California vesca has differentiated from European vesca in morphological, physiological, and biochemical characteristics. These populations were isolated ecologically and geographically and evolved considerably without the development of reproductive barriers. Thus, it is not surprising to discover that, while photo-sensitivity in the European race is controlled by a single dominant allele of a nuclear gene, the short-day individ- uals of California vesca have acquired two additional genes with dominant alleles that reinforce their photo-sensitivity. Three recessive mutant genes would be necessary to condition day-neutrality in the latter.

The hybrids of California and alpine vesca produced fruits with excellent flavor and pleasant aroma, and they are much more tolerant to mild yellow edge virus disease than alpine vesca, which is highly susceptible.

Origins of the day-neutrality and its behavior in octoploid breeding populations. At least six independent and original DN clones of octoploid $F . \times$ ananassa have been identified, and their genes for day-neutrality have been introduced into the SD cultivars (Darrow, 1966). Most recently, late-fruited F. virginiana glauca (from Utah) clearly was the source of a dominant DN gene introduced into F. $\times$ ananassa (Bringhurst and Voth, 1980). Earlier, the same trait appeared as a clonal mutant or as open-pollinated seedlings of 'Bismark' and 'Champion' in America and in Europe; the trait was described in 'Gloede' seedlings, 'Triumph', and the parents of white-fruited 'Louis Gautheir'.

Clark (1937), Darrow (1937), and Powers (1954) postulated that two or three complementary dominant and/or recessive nuclear genes were responsible for day-neutrality in $F$. $\times$ ananassa cultivars derived from 'Progressive' and 'Rockhill', introduced by S. Cooper and H. Rockhill, respectively. They postulated 9:7 and 1:3 segregations of DN : SD plants in the progenies of day-neutrals crossed to day-neutrals and day-neutrals crossed to short-day plants, respectively. However, their identification of DN genotypes was less accurate than that of Richardson (191314), who eliminated the early flowers of his seedlings in May, and scored them through October and inferred 3:1 and 1:1 segregations from similar crosses. Clark (1937), Darrow (1937), and Powers (1954) only examined their hybrids from July to September. Moreover, in all three cases, the size of segregating populations was very small. According to the first hypothesis, the five original DN clones had repeatedly and independently acquired two or three simultaneous complementary mutations at two or three specific loci to express the trait. This situation is very unlikely.

We have focused our efforts on clones derived from Utah $F$. virginiana glauca and, to a much lesser extent, on cultivars derived from both Utah $F$. virginiana and 'Rockhill'. In all cases, the evidence is compelling that day-neutrality is controlled by a single dominant allele of a nuclear Mendelian gene. The classification of $\approx 28,000$ segregating seedlings of the breeding populations and the results of the diallel experiment of 1986 comparing late and early SD and DN parents, and genetic analysis of the homozygous DN clones, strongly support the hypothesis. The probability of the recurrence of a single dominant mutation at a genetic locus is still low, but it is reasonable.

Table 4. Genetic segregation in $F$. $x$ ananassa seedlings in a complete diallel analysis of four day-neutral (DN) and four short-day (SD) parents.

\begin{tabular}{|c|c|c|c|c|c|c|c|}
\hline \multirow[b]{2}{*}{ Type of parents } & \multicolumn{3}{|c|}{$\begin{array}{l}\text { Seedlings observed } \\
\text { (no.) }\end{array}$} & \multirow{2}{*}{$\begin{array}{c}\text { Expected } \\
\text { DN:SD } \\
\text { ratio }\end{array}$} & \multirow{2}{*}{$\begin{array}{c}\text { Observed } \\
\text { percent } \\
\text { DN }\end{array}$} & \multirow[b]{2}{*}{$\chi^{2}$} & \multirow[b]{2}{*}{$P$} \\
\hline & $\overline{\mathrm{DN}}$ & $\mathrm{SD}$ & Total & & & & \\
\hline $\mathrm{SD} / \mathrm{SD} \times \mathrm{DN} / \mathrm{SD}$ & 97 & 95 & 192 & $1: 1$ & 50.5 & 0.021 & $0.8-0.9$ \\
\hline $\mathrm{DN} / \mathrm{SD} \times \mathrm{SD} / \mathrm{SD}$ & 97 & 95 & 192 & $1: 1$ & 50.5 & 0.021 & $0.8-0.9$ \\
\hline $\mathrm{DN} / \mathrm{SD} \times \mathrm{DN} / \mathrm{SD}$ & 144 & 48 & 192 & $3: 1$ & 75.0 & 0.000 & 0.0 \\
\hline $\mathrm{SD} / \mathrm{SD} \times \mathrm{SD} / \mathrm{SD}$ & 0 & 192 & 192 & $0: 1$ & 00.0 & 0.000 & 0.0 \\
\hline
\end{tabular}


Table 5. Day-neutral vs. short-day segregation of seedlings in the genetic analysis of DN/DN parents hybridized to SD/SD plants.

\begin{tabular}{|c|c|c|c|c|c|}
\hline \multirow[b]{2}{*}{ Parental types } & \multicolumn{2}{|c|}{ Observed } & \multirow{2}{*}{$\begin{array}{l}\text { Expected } \\
\text { DN:SD }\end{array}$} & \multirow[b]{2}{*}{$\chi^{2}$} & \multirow[b]{2}{*}{$P$} \\
\hline & $\mathrm{DN}$ & $\mathrm{SD}$ & & & \\
\hline$\overline{\text { Fern (S2\#5)S3 (DN/DN) }}$ & 50 & 0 & 1:0 & 0.000 & 1.00 \\
\hline Fern (S2\#6)S3 (DN/DN) & 50 & 0 & $1: 0$ & 0.000 & 1.00 \\
\hline (Mrak S1)S (DN/DN) & 50 & 0 & $1: 0$ & 0.000 & 1.00 \\
\hline Fern $(\mathrm{S} 2 \# 5) \times F$. chiloensis (PSG15) $\left(\mathrm{F}_{1}\right)(\mathrm{SD} / \mathrm{SD})$ & 54 & 0 & $1: 0$ & 0.000 & 1.00 \\
\hline Fern (S2\#6) $\times$ Douglas $(S D / S D) F_{1}$ & 76 & 0 & $1: 0$ & 0.000 & 1.00 \\
\hline Fern $(\mathrm{S} 2 \# 5) \times$ Douglas $(\mathrm{SD} / \mathrm{SD}) \mathrm{F}_{1}$ & 159 & 0 & $1: 0$ & 0.000 & 1.00 \\
\hline Fern $(\mathrm{S} 2 \# 6) \times F$. virginiana $(\mathrm{SD} / \mathrm{SD}) \mathrm{F}_{1}$ & 106 & 0 & $1: 0$ & 0.000 & 1.00 \\
\hline Fern $(\mathrm{S} 2 \# 5) \times F$. virginiana $(\mathrm{SD} / \mathrm{SD}) \mathrm{F}_{1}$ & 38 & 0 & $1: 0$ & 0.000 & 1.00 \\
\hline Mrak $\mathrm{S} 1 \times F$. chiloensis $(\mathrm{OSF}-3)(\mathrm{SD} / \mathrm{SD}) \mathrm{F}_{1}$ & 166 & 0 & $1: 0$ & 0.000 & 1.00 \\
\hline Fern $(\mathrm{S} 2 \# 5) \times F$. chiloensis $(\mathrm{OSF}-3)(\mathrm{SD} / \mathrm{SD}) \mathrm{F}_{1}$ & 86 & 0 & $1: 0$ & 0.000 & 1.00 \\
\hline Total $\left(\mathbf{F}_{1}\right)$ & 685 & 0 & $1: 0$ & 0.000 & 1.00 \\
\hline$\left(\right.$ Fern $(\mathrm{S} 2 \# 6) \times$ Douglas) $\mathrm{S} 1\left(\mathrm{~F}_{2}\right) \mathrm{DN} / \mathrm{SD} \mathrm{S} 1$ & 97 & 29 & $3: 1$ & 0.270 & $>0.50$ \\
\hline$\left(\right.$ Fern $(\mathrm{S} 2 \# 5) \times F$. virginiana) S1 $\left(\mathrm{F}_{2}\right) \mathrm{DN} / \mathrm{SD} \mathrm{S} 1$ & 53 & 17 & $3: 1$ & 0.019 & $>0.80$ \\
\hline (Fern $(\mathrm{S} 2 \# 5) \times F$. chiloensis) $S 1\left(F_{2}\right) D N / S D S 1$ & 84 & 27 & $3: 1$ & 0.016 & $>0.90$ \\
\hline Total $\left(\mathbf{F}_{2}\right)$ & 234 & 73 & $3: 1$ & 0.244 & $>0.50$ \\
\hline$($ Fern $(\mathrm{S} 2 \# 5) \times$ Douglas $) \times$ Douglas $\left(\mathrm{BC}_{1}\right)$ & 111 & 107 & $1: 1$ & 0.073 & $>0.70$ \\
\hline (Fern $(\mathrm{S} 2 \# 5) \times$ Douglas) $\times$ Pajaro $\left(\mathrm{BC}_{1}\right)$ & 115 & 109 & $1: 1$ & 0.080 & $>0.50$ \\
\hline Total $\left(\mathrm{BC}_{1}\right)$ & 226 & 216 & $1: 1$ & 0.113 & $>0.50$ \\
\hline
\end{tabular}

Table 6. Genetic segregation of offspring of day-neutral trait DN/SD of $F$. $x$ ananassa in genetic background of $F$. chiloensis (SD/SD) and F. virginiana glauca.

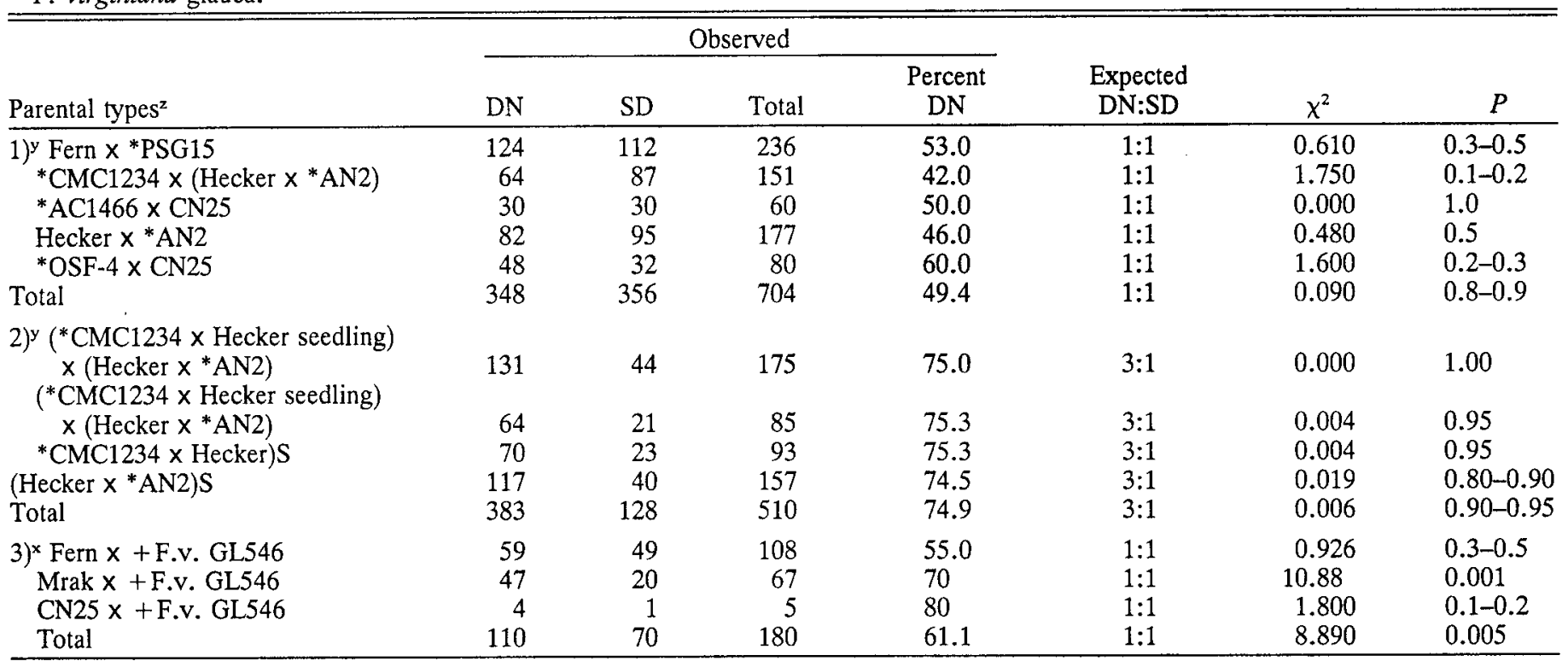

$z_{*}=F$. chiloensis, $+=F$. virginiana .

yScored in mid- and late summer

xFlowered and fruited continuously through early fall 1988 .

Classification of day-neutral genotypes in $\mathrm{F} . \times$ ananassa. The true photo-insensitive (day-neutral) genotypes in the mixed and suspected populations must be accurately classified. There are four major sources of error. First, the late-fruiting DN genotypes that do not need much chilling, when scored in late summer, in advance of the appearance of their flowers, may be classified as SD. Second, the SD genotype with the heritable characters of late fruiting and a high chilling requirement, such as 'Aiko', may, after a cold winter and mild spring, flower early and extend their sexual season or may flower continuously in the greenhouse and be considered as DN. The 'Aiko' types, how- ever, fail in progeny testing; e.g., 'New Jersey No. 1' (Clark, 1937) and their runner plants do not fruit in the nursery. Third, some SD cultivars with minimum chilling requirement may initiate flower bud formation in late August and produce a few flowers later in November and December in mild climates and may be classified as day-neutrals. Fourth, short-day-type plants carried into a 2 nd year of fruiting in a non-chilling (above $\pm 8 \mathrm{C}$ ) environment or in a greenhouse may flower semi-continuously and consequently be misjudged day-neutral.

The classification of the DN genotypes must be based on physiological behavior of the genetically controlled characters, 
such as: 1) flower bud initiation in September and fall, 2) interaction of genetic traits with environmental stimuli as heat and photoperiodic exposure in fruiting habits, 3) physiological switch of sexual and vegetative cycles, and 4) chilling requirements. The most efficient way of handling and scoring the segregants is to germinate them in late winter to early spring, establish them in the field in the spring, and tabulate their flowering and fruiting occasions from mid-summer to early fall. The SD seedlings under this physiological regime do not initiate flower buds and continue with their vegetative cycle, while the DN plants initiate their sexual reproduction, prolong their sexual cycles, and commingle them with reduced vegetative reproduction.

Apparent DN phenotypes maybe test-crossed to $F$. chiloensis, since genes that modify the photoperiodic response are absent, as is frequently the case in SD type $F$. $\times$ ananassa cultivars. The DN seedlings usually flower after 3 to 4 months in the greenhouse or in the field and the SD genotypes do not flower in the first year and their sexual reproductive season is very short in the 2 nd year. The genetic background of $F$. virginiana glauca, however, is not suitable for the progeny test because it may carry genes that confound the photoperiodic response.

Photoperiodism in the interspecific and intergeneric hybrids. The dominant day-neutrality character of $F . \times$ ananassa is expressed in other species of Fragaria. It can be employed to speed up the turnover of the generations of seedlings and to accurately reveal the inheritance of the genetic traits, such as sex expression, isozyme classification, molecular transformation, disease resistance, and desirable agronomic and botanical characteristics. Moreover, the DN gene expresses itself in intergeneric background and may speed up the transfer of desirable traits from Potentilla to Fragaria populations. Potentilla fruticosa may be hybridized to SD or DN clones of $F . \times$ ananassa. The hybrids usually require GA treatments to grow properly. Potentilla glandulosa may not hybridize with $F . \times$ ananassa, but hybridizes readily with $F$. chiloensis and the hybrids are compatible with $F$. $\times$ ananassa. The interspecific hybrids between $F$. $\times$ ananassa and $F$. chiloensis are also compatible with $P$. glandulosa.

\section{Literature Cited}

Bernier, G., J.M. Kinet, and R.M. Sachs. 1981, The physiology of flowering. CRC Press, Boca Raton, Fla.

Bringhurst, R.S. and V. Voth. 1980. Six new strawberry varieties released. Calif. Agr. 34: 12-15.

Bringhurst, R.S., H. Ahmadi, and V. Voth. 1989. Inheritance of the day-neutral trait in strawberries. Chronica Hort. (In press).

Brown, T. and P.F. Wareing. 1965. The genetical control of the everbearing habit and three other characters in varieties of Fragaria vesca. Euphytica 14:97-1 12.

Chailakhyan, M.K.H. 1979. Genetic and hormonal regulation of growth, flowering, and sex expression in plants. Amer. J. Bot. 66:717-736.

Chandrartna, M.F. 1953. A gene for photo period sensitivity in rice linked with apiculus colour. Nature (London) 171:1162-1163.

Chandrartna, M.F. 1955. Genetics of photoperiod sensitivity in rice. Genetics 53:216-223.
Clark, J.H. 1937. Inheritance of so-called everbearing tendency in the strawberry. Proc. Amer. Soc. Hort. Sci. 35:67-70.

Darrow, G.M. 1937. Strawberry improvement. USDA Yrbk. 1937:445495.

Darrow, G.M. 1966. The strawberry, history, breeding and physiology. Holt, Rinehart and Winston, New York.

Della, P.T., and C.E. Peterson. 1984. Inheritance of flowering response in cucumber. J. Amer. Soc. Hort. Sci. 109:761-763.

Garner, W.W. and H.A. Allard. 1920. Effect of the relative length of day and night and other factors of the environment on growth and reproduction in plants. J. Agr. Res. 18:553-606.

Guttridge, C.G. 1959. Further evidence for a growth-promoting and flower-inhibiting hormone in strawberry. Ann. Bot. 23:612-621.

Hancock, J.F., Jr., and R.S. Bringhurst. 1978. Inter-populational differentiation and adaptation in the perennial, diploid species Fragaria vesca L. Amer. J. Bot. 65:795-803.

Joshae, D.C. and R.G. Thakare. 1986. A day-neutral mutant in jute. Trop. Agr. 63:316-318.

Knott, D.R. 1986. Effect of genes for photoperiodism, semidwarfism and awns on agronomic character in a wheat cross. Crop Sci. 26:11581162.

Kotecha, A.K., D.M. Yermanos, and F.M. Shropshire. 1975. Flowering in cultivars of sesame seasmum indium differing in photoperiodic sensitivity. Econ. Bot. 29:185-191.

Lang, A. 1984. The photoperiodic regulation of promotion and inhibition of flower formation. Ber. Dutsch. Bot. Ges. 27:293-314.

Lewis, C.F., and T.R. Richmond. 1957. The genetics of flowering response in cotton: I. Fruiting behavior of Gossypium hirsutum var. Marie-Galante in a cross with a varity of cultivated American upland cotton. Genetics 42:499-509.

Lewis, C.F. and T.R. Richmond. 1960. The genetics of flowering response in Gossypiun barbadense cross. Genetics 45:79-85.

Maystrenko, 0.I. and E.B. Aliev. 1986. Chromosomal location of genes for photoperiodic response in a winter common wheat variety skoro-spelka-35 slightly sensitive to short daylight. Cereal Res. Commun. 14(1):41-48.

Nicoll, N.F., and G.J. Galletta. 1987. Variation in growth and flowering habits of June bearing and everbearing strawberries. J. Amer. Soc. Hort. Sci. 112:872-880.

Powers, L. 1945. Strawberry breeding studies involving crosses between the cultivated varieties (Fragaria $\times$ ananassa) and the native Rocky Mountain strawberry (F. ovalis). J. Agr. Res. 70:95-122.

Powers, L. 1954. Inheritance of period of blooming in progenies of strawberries. Proc. Amer. Soc. Hort. Sci. 64:293-298.

Richardson, C.W. 1913-14. A preliminary note on the genetics of Fragaria. J. Genet. 3:171-177.

Ross, J.J. and I.C. Murfet. 1985. Flowering and branching in Lathyrus odoratus environmental and genetic effects. Ann. Bot. 55:715-726.

Ross, J.J. and I.C. Murfet. 1986. A comparison of the flowering and branching control system in Lathyrus odoratus and Pisum sativum. Ann. Bot. 56:847-856.

Salisbury, P.A., Y. Aiker, and G.M. Halloran. 1987. Genetic control of flowering time and its component processes in subterranean clover (Trifolium subterraneum L.). Euphytica 36:887-902.

Skripchinsky, V.V. 1971. Genetics of photoperiodism in angiosperms. Genetika 7:140-152.

Wyatt, J.E. 1985. Inheritance of photoperiod sensitivity, hirsute seed, and albinism in okra. J. Amer. Soc. Hort. Sci. 110:74-78. 